University of Nebraska - Lincoln

DigitalCommons@University of Nebraska - Lincoln

USDA National Wildlife Research Center - Staff

Publications

U.S. Department of Agriculture: Animal and Plant Health Inspection Service

2013

\title{
Wildlife in managed forests: An overview of perspectives from the Pacific Northwest
}

Jimmy D. Taylor II

USDA/APHIS/WS National Wildlife Research Center, jimmy.d.taylor@usda.gov

Follow this and additional works at: https://digitalcommons.unl.edu/icwdm_usdanwrc

Part of the Life Sciences Commons

Taylor, Jimmy D. II, "Wildlife in managed forests: An overview of perspectives from the Pacific Northwest" (2013). USDA National Wildlife Research Center - Staff Publications. 1576.

https://digitalcommons.unl.edu/icwdm_usdanwrc/1576

This Article is brought to you for free and open access by the U.S. Department of Agriculture: Animal and Plant Health Inspection Service at DigitalCommons@University of Nebraska - Lincoln. It has been accepted for inclusion in USDA National Wildlife Research Center - Staff Publications by an authorized administrator of DigitalCommons@University of Nebraska - Lincoln. 
Editorial

\section{Wildlife in managed forests: An overview of perspectives from the Pacific Northwest}

\section{Introduction}

Humans rely on forests for fiber, food, water, shelter, recreation, inspiration, and various other benefits. Similarly, many species of native fauna depend on forests to meet their seasonal and annual requirements. Forests in the Pacific Northwest have a longstanding history of providing high quality forest products, and ownership across a complex matrix of forest stands is divided among provincial, federal, state, tribal, and private entities. Over time, requirements to provide forest products have increasingly rested with industrial and non-industrial private landowners. Concomitantly, forest management has evolved and intensified on private lands in response to increases in national and global demand for forest products, increasing urbanization, shifting policy on public forests, and a more complex regulatory environment.

Concomitant management for biodiversity and timber production is expected by both stakeholders and forest certification systems on industrial forests in North America. Nowhere is this more important than in the diverse Pacific Northwest. Understanding how changes in the intensity of silvicultural practices affect habitat characteristics and wildlife populations is integral to informing forest management and policy and meeting expectations of stakeholders and certification systems.

Intensive silvicultural practices for Pacific Northwest conifer plantations typically include harvesting most of the merchantable trees from timber stands, followed by mechanical site preparation, herbicide treatment to control competing vegetation, and replanting the area with commercial conifer seedlings. Genetically selected seedlings are planted at densities that maximize stand potential and may include measures to reduce damage by wildlife, assuming a relative loss of trees to competition and shading. Intermediate practices may include thinning, herbicide application, and fertilization; however, recent modifications in silvicultural systems include changes in the use of tools to enhance forest productivity (e.g., fertilizers, herbicides) and an increased emphasis on producing a wide range of bioenergy feedstocks from forested landscapes. In response to stakeholder concerns about implications of these changes for sustainability and environmental impacts, commercial forest managers often implement measures such as "green tree retention" or "biomass harvesting guidelines" which may be voluntary or regulatory. Although these measures are intended to enhance sustainability and achieve conservation goals, empirical evidence documenting wildlife community response is often lacking and, thus, there may be little technical basis for judging efficacy of or guiding improvements in these practices.

\section{This special section: wildlife in managed forests}

This special section includes selected presentations from a symposium held at the Annual Conference of The Wildlife Society (TWS) on 14 October, 2012 in Portland, Oregon, USA, along with one separate submission. The symposium was jointly sponsored by the Forestry and Wildlife Working Group of TWS; the Biological Diversity Working Group of TWS; National Council of Air and Stream Improvement (NCASI); Oregon Forest Industries Council (OFIC); Oregon Forest Resources Institute (OFRI); Washington Forest Protection Association (WFPA); Sustainable Forestry Initiative (SFI), Oregon State Implementation Committee; and USDA, APHIS, WS, National Wildlife Research Center (NWRC). The purpose of the symposium was to share knowledge of the relationships between current and variable practices for intensive forest management and faunal diversity in the Pacific Northwest. Although the Pacific Northwest is an expansive region, the list of invited speakers was limited to research conducted in intensively managed conifer forests of western British Columbia, Washington, Oregon, and California.

Four of the five papers evaluated bird responses to silvicultural practices. Irwin et al. (2013) used radio-telemetry to quantify space use of northern spotted owls (Strix occidentalis caurina; hereafter owls) in the dry mixed conifer and mesic coastal redwood zones of Oregon and California. They found owls preferentially used harvest-created hardwood/evergreen shrub patches as far as $600 \mathrm{~m}$ from forests for foraging in winter. Furthermore, approximately $20 \%$ of owls in mixed conifer forests migrated to lower elevations in winter. They also found the greatest use of harvested units by owls in stands with $10-18 \mathrm{~m}^{2}$ /ha of conifer basal area. Their findings suggest that active forest management in these zones is compatible with recovery goals, as required by the United States Fish and Wildlife Service's revised recovery plan for the northern spotted owl (USFWS, 2011).

Herbicides are often used in intensively managed forests to control competing vegetation, especially during stand initiation. Betts et al. (2013) presented two years of results from a manipulative experiment in which three levels of herbicide treatment and a control (no herbicide) were applied to sites planted with Douglas-fir (Psuedotsuga menziesii) in the Oregon Coast Range. They found that reducing intensity of herbicides during site preparation has positive effects on early seral bird abundance during the first two years of stand initiation. Furthermore, they recommended that additional research is necessary to examine the tradeoffs between tree growth and reduction in herbicide application in order to balance timber production and biodiversity. 
Retention of green trees, snags, and downed wood in clearcut harvest units is used to provide habitat for wildlife. Linden and Roloff (2013) measured retained elements and surveyed forest birds in clearcut forest stands from central Washington to northern California. They observed a total of 71 songbird and woodpecker species using clearcuts, while mean stand level richness ranged from 30-38 species. Using a multi-scale, multi-species occupancy model, they found members of the forest community in each region valued clearcuts with retention differently.

The final bird-related paper in this special section was not part of the symposium, nor was it conducted on intensively managed industrial forests; however, the research approach, the location of the study, and the treatment effect (thinning) were relevant to our special topic. Commercial thinning is an intermediate silvicultural practice used in intensively managed forests. Yegorova et al. (2013) examined bird-vegetation relationships for eight common bird species during ten years following thinning operations in young Douglas-fir forests in the western Cascade region of Oregon. They found the magnitude of bird-vegetation relationships to be highly variable across years, with six bird species experiencing consistently positive or negative relationships to vegetation. They warn others to be cautious when interpreting weak bird-habitat relationships found in short-term studies.

In the fifth and final paper of this special section, Sullivan et al. (2013) presented results from long-term monitoring efforts in British Columbia, Canada, evaluating the responses of small arboreal and forest-floor mammals to stand thinning and fertilization in young lodgepole pine (Pinus contorta) forests. Mean species diversity of forest-floor small mammals differed among stands over a 21-year period and favored stands that received pre-commercial thinning treatments; however, the addition of fertilization had no detectable effect on mean species diversity of small mammals. Mean abundance of red-backed voles (Myodes gapperi) was highly variable but was generally greater in old-growth stands where mean species diversity and mean structural diversity of conifers was lower. Overall, they found small mammal diversity may be maintained with a variety of silvicultural prescriptions that include a wide range of stand densities from pre-commercial thinning and nutrient additions in intensively managed forests.

Increased collaboration among forest and wildlife research scientists is necessary to improve our knowledge of wildlife diversity and population dynamics throughout forest landscapes in North America. As seen from some of the papers presented in this special section, long-term monitoring is necessary to make informed decisions. A similar symposium focused on wildlife in intensively managed forests of the eastern United States will be offered at The Wildlife Society's 20th annual conference in Milwaukee, WI.

\section{Acknowledgements}

I would first like to thank Larry Irwin for the major roles he played in conceptualizing the symposium and in securing speakers. Jenniffer Bakke, Jessica Homyack, and Ben Wigley also were critical in co-organizing the symposium. Special thanks go to Todd Fredericksen for his tireless efforts in serving as overseeing editor for this special section.

\section{References}

Betts, M.G., Verschuyl, J., Giovanini, J., Stokely, T., Kroll, A.J., 2013. Initial experimental effects of intensive forest management on avian abundance. Forest Ecol. Manage. 310, 1042-1050.

Irwin, L.L., Rock, D.F., Rock, S.C., 2013. Do northern spotted owls use harvested units? Forest Ecol. Manage. 310, 1035-1041.

Linden, D.W., Roloff, G.J., 2013. Retained structures and bird communities in clearcut forests of the Pacific Northwest, USA. Forest Ecol. Manage 310, 10511062.

Sullivan, T.P., Sullivan, D.S., Lindgren, P.M.F., Ransome, D.B., 2013. Stand structure and small mammals in intensively managed forests: scale, time, and testing extremes. Forest Ecol. Manage. 310, 1077-1093.

United States Fish and Wildlife Service (USFWS), 2011. Revised recovery plan for the northern spotted owl, Strix occidentalis caurina. US Fish and Wildlife Service, Portland, OR, USA.

Yegorova, S., Betts, M.G., Hagar, J., Puettmann, K.J., 2013. Bird-vegetation associations in thinned and unthinned young Douglas-fir forests ten years after thinning. Forest Ecol. Manage. 310, 1063-1076.

Jimmy D. Taylor

U.S. Department of Agriculture, Animal Plant Health Inspection Service, Wildlife Services, National Wildlife Research Center, Oregon Field Station, 321 Richardson Hall, Corvallis, OR 97331, USA Tel.: +1 5417371353 .

E-mail address: jimmy.d.taylor@aphis.usda.gov 